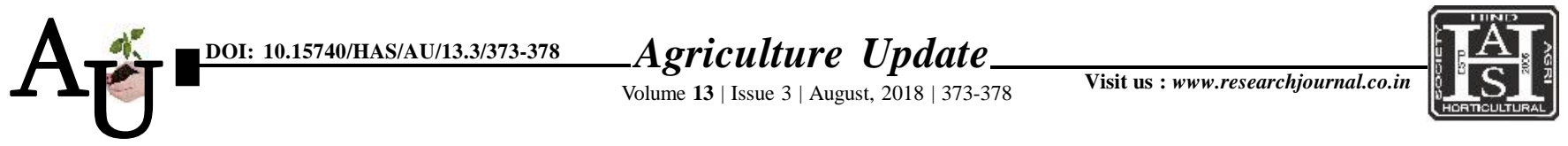

— e ISSN-0976-6847

\title{
A Case Study: $\quad$ Major issues of tomato growers in Madanapalli division of Andhra Pradesh
}

\author{
Prasanna Lakshmi Ravuri and P. Ganesh Kumar
}

Article Chronicle : Received :

12.06.2018;

Accepted :

26.07.2018
SUMMARY : Tomato is one of the most popular vegetable crop in India. It is a high value crop, providing a good source of income to small scale farmers. In Chittoor district of Andhra Pradesh tomato is grown in an area of 20,000 ha throughout the year. Of which, $75 \%$ of tomato area is in Madanapalli division which is one among biggest revenue divisions in India. Despite of huge market facilities in the division, farmers are facing series of constraints during cultivation and marketing. Non-availability of quality seedlings, pest incidence throughout the year, increase in cost of cultivation, fluctuations in market price and malpractices in regulated markets are the major constraints faced by farmers in the division despite farmers are reaping good yields.

How to cite this article : Ravuri, Prasanna Lakshmi and Kumar, P. Ganesh (2018). Major issues of tomato growers in Madanapalli division of Andhra Pradesh. Agric. Update, 13(3): 373-378; DOI : 10.15740/HAS/AU/ 13.3/373-378. Copyright@ 2018: Hind Agri-Horticultural Society.

KEY Words:

Tomato production, Constraints, Madanapalli division

Author for correspondence :

\section{Prasanna Lakshmi} Ravuri

Krishi Vigyan Kendra, Kalikiri, Chittoor (A.P.) India

Email : pras.agrico@ gmail.com

See end of the article for authors' affiliations 